\title{
KONSEP ILMU DALAM ISLAM DAN IMPLIKASINYA \\ DALAM PRAKTIK KEPENDIDIKAN
}

\author{
Sarjuni \\ Fakultas Agama Islam Universitas Islam Sultan Agung (UNISSULA) Semarang \\ sarjuni@unissula.ac.id / alfahanin@gmail.com
}

\begin{abstract}
Islam as a worldview has a different point of view from other religion and civilisation perspective to see the world. This point of view is reflected and accumulated in the key concept understood from the main Islamic teaching source, Al-Qur'an and Sunnah. For example, related to the concept of science in the western civilisation.

The concept of science in Islam has an effect on the goal orientation of Islamic education, that is different from the goal orientation of the western education. These Islamic Education goal are: Producing human being, having a good moral value, who can put something based on the real honor, using the right ways to reach the correct goal, and struggling for something to reach the right goal.

The concept of science in Islam has an orientation to curriculum and classroom learning process. The education curriculum has to be developed integrally. Integrate between fardhu 'ain and fardhu kifayah science development. In addition, the implementation of this can be dinamic. In the learning process of courtesies related to the science, the courtecies of the relationship between teacher and student in the educative interaction has to be implemented.
\end{abstract}

Keywords: The concept of science, courtecy, and education

Abstrak

Islam sebagai sebuah pandangan hidup (worldview) memiliki cara pandang yang berbeda dengan cara pandang agama dan peradaban lain dalam melihat sesuatu. Cara pandang ini tercermin dan terakumulasi dalam konsepkonsep kunci yang dipahami dari sumber utama ajaran Islam yakni al-Qur'an dan sunnah. Misalnya, terkait dengan konsep ilmu. Konsep ilmu dalam Islam berbeda sekali dengan apa yng dimaksud dengan ilmu dalam peradaban Barat.

Konsep ilmu dalam Islam berimplikasi pada orientasi tujuan pendidikan Islam yang juga berbeda dengan orientasi tujuan pendidikan model Barat, yakni mewujudkan manusia-manusia yang beradab, yang mampu menempatkan sesuatu sesuai dengan martabat yang sebenarnya, menggunakan cara-cara yang benar untuk mencapai tujuan yang benar, dan memperjuangkan sesuatu untuk mencapai tujuan yang benar.

Konsep ilmu dalam Islam juga berorientasi pada kurikulum dan proses pembelajaran di kelas. Kurikulum pendidikan harus dikembangkan secara integral, tidak dikotomis. Integral antara pengembangan ilmu fardhu 'ain dan fardhu kifayah sekaligus, yang pelaksanannya bisa berifat dinamis. Dalam proses pembelajaran adab-adab yang terkait dengan ilmu, adab hubungan guru dan peserta didik dalam interaksi edukatif harus diimpementasikan.

Kata Kunci: Konsep ilmu, Adab, dan Pendidikan 


\section{A. MAKNA ILMU}

Istilah "ilmu" sering dipahami sebagai sesuatu yang sama dengan sciencedalam bahasa Inggris, wissenschaft (Jerman) dan etenschap (Belanda), yang bermakna "tahu". Term "ilmu" berasal dari kata 'alima' (Arab) yang berakna mengetahui. Dengan demikian secara bahasa ilmu kata ilmu berakna pengetahuan. Namun demikian secara istilahi terdapat perbedaan yang cukup jelas antara pengertian atau definisi yang dikemukakan oleh para ilmuwan pada umumnya a, dengan pengertian yang dikemukakan oleh saintis muslim khusunya.

Endang Saifuddin Anshari (I985) menyitir beberapa pengertian ilmu (science) dari para pemikir, diantaranya Karl Pearson dalam bukunya Grammar of Science, merumuskan : "Science is the complete and consistent description of the facts of experience in the simplest possible terms" (Ilmu pengetahuan ialah lukisan keterangan yang lengkap dan konsisten tentang fakta pengalaman dengan istilah yang sederhana atau sesedikit mungkin). Menyitir definisi Baiquni, Anshari mengatakan bahwa : "Science sebagai general concensus dari komunitas ilmuwan”.

Pengertian-pengertian tersebut di atas menunjukan bahwa, ilmu adalah pengetahuan yang mempunyai ciri-ciri, code, dan persyaratan tertentu, yaitu: "sistematik, rasional, empiris, umum, dan kumulatif (bersusun timbun)”. Dengan istilah lain, ilmu adalah pengetahuan yang tersusun secara sistematis yang diperoleh melalui langkah-langkan metodologi ilmiah, baik tentang perilaku sosial, budaya, maupun gejala-gajala alam yang dapat diamati dan diukur.

Unsur-unsur terpenting ilmu meliputi : Sistem, yang berfungsi untuk membadakan objek kajian ilmu yang satu dengan ilmu lainnya, yang sering diebut dengan aspek ontologi. Metode, cara yang dipakai ilmuwan untuk memahani objek studi, yang sering dikenal dengan istilah epistemologi. Fakta, deskripsi tentang gejala-gejala yang ada pada objek studi, dan Teori, yaitu seperangkat pernyataan logis dan sistematis tentag gejala-gejala yang diamati..

Sedangan pengertian ilmu yang disampaikan oleh pemikir muslim kontemporer, yakni al-Attas, di dalam karya-karyanya yang membahas tentang ilmu pendidikan berbeda dengan ilumuwan-ilmuwan pada umunya. Beliau menyatakan:

"Science is all knowledge comes from God and is interpreted by the soul trought its spiritual and physical faculties and senses, it follow that knowledge, with reference to God as being its origin, is the arrival (husul) in the soul of the meaning (ma'na) of a thing or an object of knowledge ; and with reference to thr soaul as being its interpreter, knowledge is the arrival (wusul) of the soul at the meaning of a thing or an object of knowledge" (al-Attas, 200I).

Pengertian ilmu tersebut jika dirumuskan dalam kalimat yang lebih sederhana menjadi: "Ilmu itu tibanya ma'na sesuatu pada diri, dan berhasilnya diri menyerapinya." (Isma'il, 2007). Dari pembahasan di atas maka konsep ilmu dalam definisinya memiliki kandungan makna sebagai berikut:

I. Pencapaian ilmu melibatkan Allah dan manusia Uraian di atas mengandung makna bahwa perolehan ilmu selalu melibatkan dua pihak yakni yang memberi dan yang menerima.. Allah adalah pemberi ilmu dan manusia sebagai yang merimanya. Jadi, sumber ilmu yang sebenarnya adalah Allah, dan manusia adalah penerima anugerah ilmu dan kefahaman.

2. Proses epistemologis melibatkan segi aktif dan pasif Secara epistemologis pencapaian ilmu terdiri atas dua segi yaitu, segi pasif dan segi aktif. Segi pasif nampak dalam kalimat "the arrival in the soul of the meaning of a thing or an object of knowledge"; dan segi aktif mengarah kepada manusia sebagai penimba ilmudengan kehendak yang kuat.

Meskipun secara epistemologi proses pencapaian ilmu selalu melibatkan dua segi, yakni pasif dan aktif, namun kadar kekuatan kedua segi tersebut berbeda-beda sesuai dengan tingkat kecerdasan dan jenis-jenis ilmu yang dipelajari seseorang. Ada jenis-jenis ilmu yang cara mendapatkannya lebih membutuhkan segi pasif dan ada juga jenis ilmu yang usaha untuk mendapatkannya lebih membutuhkan segi aktif. Pada dasarnya, ilmu-ilmu yang segi pasifnya lebih kuat dinamakan ilmu makrifat.

Sedangkan ilmu pengetahuan yang segi aktifnya lebih kuat sering disebut dengan sains. Ilmu makrifat inilah yang lazimnya masuk dalam kategori ilmu-ilmu fardhu 'ain (Al-Attas, I98I) 
3. Informasi sebagai sarana utama pencapaian ilmu

Informasi pada hakikatnya merupakan apaapa yang hadir kepada kita baik melalui instrumen indrawi seperti penglihatan, pendengaran, perasaan, penciuman dan perabaan, maupun akali. Informasi mempunyai berbagai macam bentuk yakni: angka, data, warna, corak, gambar, bunyi, suara, lambang, teks, dan sebagainya. Informasi itu bukan ilmu akan tetapi untuk mendapatkan ilmu sangat dibutuhkan informasi. Artinya seseorang tidak bisa mendapatkan ilmu tanpa adanya informai yang hadir kepadanya. Karenanya transformasi ilmu selalu menggunakan wasilah informasi.

Misalnya, guru ketika mengajar selalu memberikan informasi dalam bentuk bahasa maupun alat-alat peraga, yang dalam istilah sehari-hari sering disebut dengan "komunikasi". Murid memperhatikan dengan seksama informasi yang disampaikan oleh guru. Ketika kemudian murid dapat memahami apa yng disampaikan oleh guru berarti murid mendapatkan ilmu, yakni "kefahaman". Kefahaman ini dalam Islam diyakini sebagai anugerah dari Allah. Jadi sebaik apapun cara guru mengajar dan setekun apapun murid belajar kalau Allah tidak menganugerahkan kefahaman, maka murid tidak akan memperoleh ilmu. Inilah sebabnya sama-sama mendengarkan informasi dari sumber yang sama kefahaman setiap individu berbeda-beda.. (AlAttas, 1995).

Pengalaman indrawi adalah tahap pertama pemrosesan informasi oleh akal diri untuk mencapai makna, kefahaman dan ilmu pengetahuan. Proses pengolahan informasi oleh akal diri untuk mendapatkan makna, kefahaman, dan ilmu pengetahuan, sering disebut dengan abstraksi, dimana Allah juga mengambil peran di dalamnya.

\section{B. PEMBAGIAN ILMU DALAM ISLAM}

Al-Ghazali membagi ilmu ke dalam dua kelomok, yakni ilmu fardhu 'ain dan ilmu fardhu kifayah. Ilmu fardu 'ain adalah ilmu yang diwajibkan atas tiap-tiap individu sedangkan ilmu fardhu kifayah adalah ilmu yang diwajibkan kepada umat Islam secara kolektif. Jadi fardhu 'ain adalah kewajiban individu per individu sedangkan fardhu kifayah adalah kewajiban umat Islam secara keseluruhan. Implikasi dosa jika ilmu farhu 'ain tidak dilaksanakan adalah ditanggung individu, sementara implikasi dosa jika ilmu fardhu kifayah tidak dilaksanakan ditanggung bersama-sama anggota mayarakat.

I. Ilmu Fardhu 'ain

Sebagaimana disampaikan oleh ulama salaf, ilmu yang bersifat fardhu untuk dipelajari oleh setiap muslim adalah ilmu yang mau tidak mau harus dipelajari oleh umat Islam. Ilmu fardhu 'ain wajib bagi semua manusia, baik bagi masyarakat awam atau para ulama.

a.Dimensi Pertama Ilmu Fardhu 'ain

Dimensi pertama $1 \mathrm{lmu}$ fardhu 'ain adalah ilmu tetang aqidah yaitu, ilmu yang membenarkan segala sesuatu yang benar, yang disampaikan Allah kepada Rasulullah dengan itiqad yang kuat tanpa keraguan. Dimensi pertama ilmu fardhu 'ain ini juga disebut dengan ilmu tauhid, karena ruang lingkupnya adalah berupa $m$ a'rifatullah.

Tingkat kedalaman ilmu yang wajib dipalajar oleh seoang muslim yang satu dengan muslim yang lain berbeda-bedaan sesua dengan keadaan masingmasing. Ada orang-orang sampai membutuhkan argumen-argumen rasonal-logis-filosofis untuk sampai kepada sebuah keyakinan yang kuat. Namn ada pula orang-orang yang hanya cukup medapatkan penjelasan dengan menggunakan ayat-ayat al-Qur'an dan hadishadis Rasulullah untuk samai kepada sebuah keyakinan yang kuat. Demikian pula karena buah daripada iman adalah akhlakul karimah, maka ilmu fardhu 'ain ini mencakup hal-hal yang bersifat lahiriyah dan ruhaniah sekaligus.

b. Dimensi kedua Ilmu Fardhu 'ain

Dimensi kedua ilmu fardhu 'ain adalah berhubungan dengan hal-hal yang wajib dilaksanakan oleh seorang mukallaf. Terkait dengan hal ini berlaku beberapa ketentuan berikut ini:

\section{I) Ketentuan Pertama}

Bahwa kewajiban seorang mukallaf mengalami perkembangann sesuai dengan bertambahnya usia, sehingga kewajiban mempelajari ilmu fardhu 'ain tentang ha-hal yang wajib dilaksanakan bersifat dinamis.

Ilmu-ilmu fardhu 'ain amal apa saja yang harus dipelajari seseorang berbeda-beda, karena perbedaan keadaan, kedudukan, dan perbedaan kebutuhan hidup seeorang 
(Adi Setia, 2007).

2) Ketentuan Kedua

Ketentuan kedua untuk menentukan ilmuilmu fardhu 'ain yang behubungan dengan amal yang wajib dikerjakan adalah adanya ketentuan "larangan bagi mukallaf untuk melakukan sesuatu sebelum dia memahami ketentuan-ketentuan di dalam agama”. Misalnya, seseeorang boleh melakukan praktik perdagangan jika yang bersangkutan sudah memahami dengan benar hukum-hukum yang berkaitan dengan mu' amalah dalam Islam. Seseorang boleh terjun ke dunia perpolitikan jika sudah memahami hukum-hukum Islam yang berhubungan dengan fiqih syiyasyah dan lainlain. Jika ilmu fardhu 'ain yang berhubungan dengan aqidah mutlak wajib untuk setiap orang kapanpun dan dimanapun, maka ilmu fardhu 'ain yang berkenaan dengan amalan-amalan tertentu sebagaimana contoh di atas, hanya diwajibkan kepada siapa-siapa yang hendak melaksanakannya.

c. Dimensi Ketiga Ilmu Fardhu 'ain

Dimensi ketiga ilmu fardhu 'ain adalah berhubungan dengan apa-apa yang dilarang oleh Allah Swt untuk melaksanakannya. Dengan kata lain adalah ilmu-ilmu tentang perkara-perkara yang diharamkan Allah Swt. Dalam hal ini juga berlaku ketentuan dinamis sebagaimana ilmu yang berkaitan dengan hal-hal yang wajib dilaksanakan. Artinya kewajiban untuk mempelajari ilmu-ilmu tentang perkara yang wajib ditinggalkan pun berkembang sesuai dengan keadaan seseorang. Misalnya ada masalah yang wajib ditinggalkan oleh orang yang normal berbeda dengan yang harus ditinggalkan oleh orang bisu dan tuli, dan sebagainya.

Kewajiban untuk mempelajari hal-hal yang diharamkan juga meliputi hal-hal yang bersifat jasmaniah dan ruhaniah sekaligus. Takabur, kufur nikmat, tafakhur, riya, ghibah, tajassus, dan lain-lain adalah beberpa contoh perbuatan yang wajib ditinggalkan yang harus dipelajari secara mendalam sehingga umat Islam terjauh dari sifat-sifat negatif tersebut.

\section{Ilmu Fardhu Kifayah}

Imam al-Ghazali menjelaskan bahwa ilmu fardhu kifayah memiliki dua kriteria. Kreteria pertama, yaitu ilmu-ilmu yang menjadi prasyarat bagi tegaknya urusan agama, seperti ilmu tajwid, ilmu tafsir, ilmu hadis, ilmu ushul fiqih, ilmu fiqih, dan sebagainya (Zaidi Ismal, 2007). Hal ini merupakan pengejawantahan dari firman Allah di dalam al-Qura'an: "Tidak sepatutnya bagi mukminin itu pergi semuanya (ke medan juang). Mengapa tidak pergi dari tiap-tiap golongan di antara mereka beberapa orang untuk memperdalam ilmu agama dan untuk memberi peringatan kepada kaumnya apabila mereka telah kembali kepadanya, supaya mereka itu dapat menjaga dirinya." (QS. At-Taubah : I22)

Ilmu yang diwajibkan sebagai prasyarat khusus memiliki perbedaan dengan wajib pada umumnya mukallaf. Misalnya adalah hal-hal yang terkait dengan rukun iman dan hal-hal yang berkaitan dengan dasardasar syariat Islam. Wajib untuk ilmu-ilmu prayarat berbeda antar orang yang satu dengan yang lain bergantung pada konteks zaman, kebutuhan masingmasing, tingkat keerdasan dan lain-lain. Setiap muslim diwajibkan untuk belajar ilmu-ilmu yang dibutuhkan oleh masyarakat. Mukallaf secara secara umum diwajibkan untuk mengkaji ilmu syariat berdasarkan pada tingkat kebutuhan masyarakat guna memahami sumber ajaran Islam, tanpa harus memasuki masalahmasalah yang berat dan rumit. (Zaidi Isma'il, 2007).

Masuk dalam kategori ilmu fardhu kifayah selanjutya adalah ilmu-ilmu yang dewasa ini sering disebut sebagai ilmu-ilmu umum, seperti ilmu kedokteran, ilmu keperawatan, ilmu teknik, ilmu ekonomi, ilmu peternakan, ilmu pertanian, dan lain-lain. Ilmu-ilmu terebut meskipun bukan ilmu agama tetapi keberadaannnya sangat dibutuhkan guna memenuhi kebutuhan duniawiah masyarakat muslim. Jika ilmu-ilmu tersebut idak dikuasai oleh umat Islam dipastikan umat Islam akan mengalami kesulitan dalam mempertahankan ekistensi hidunya. Terutama ketika harus berkompetisi dengan umat lain yang sangat serius dalam mempelajari ilmu-ilmu tersebut.

"Cendekiawan Melayu kontemporer al-Attas dalam buku Islam and Secularism memasukkan ilmuilmu kemanusiaan, sains alam, sains terapan, sains teknologi, perbandingan agama, kebudayaan dan tamadun Barat, ilmu-ilmu bahasa, dan sejarah Islam sebagai sejarah dunia yang merangkum pemikiran, kebudayaan dan tamadunnya, serta perkembangan sistem 
dan filsafat ilmunya, ke dalam bidang ilmu-ilmu fardhu kifayah. Semua ilmu tersebut harus diserasikan dengan kerangka Pandangan Hidup Islam. “

Kewajiban atas ilmu fardhu kifayah ditanggung bersama-sama secara kolektif oleh masyarakat. Jika beberapa mukallaf ada yang mempelajari ilmu fardhu kifayah tersebut, maka kewajiban tersebut telah dipenuhi, dan anggota masyarakkat terbebas dari dosa. Sebaliknya, jka tidak ada seorangpun yang menuntut ilmu fardhu kifayah tersebut, maka semua mukallaf yang ada di komunitas tersebut menanggung dosa.

Ilmu-lmu tersebut wajib dipelajari oleh umat Islam, akan tetapi Allah tidak memerintahkan kepada semua individu untuk menimbanya. Semua anggota masyarakat boleh menimba ilmu-ilmu tersebut. Kebutuhan dan kemaslahatan umat akan tercukupi dengan adanya sebagian individu yang menguasai ilmu-ilmu tersebut, jadi tidak perlu semua orang untuk menekuni ilmu-ilmu tersebut.

Individu yang mempunyai minat dan bakat serta kemampuan dana yang memadahi untuk mendalami ilmu fardhu kifayah mejadi wajib baginya untuk mendalaminya. Orang yang terjun untuk mendalami ilmu fardhu kifayah tertentu, maka bagi yang bersangkutan menjadi fardhu 'ain untuk mendalamninya. Bahkan jika orang terebut kurang mampu secara finansial, masyarakat secara bersama-sama berkewajiban untuk membantunya agar orang tersebut dapat menyelesaikan studinya. Dalam hal ini pemerintah wajib memenuhi kebutuhan dana untuk studinya.

Jika kewajiban menimba ilmu fardhu kifayah sampai dilupakan, yang mengakibatkan kemaslahatan masyarakat menjadi terabaikan, orang-orang yang berkemampuan menanggung dosanya, demikian juga orang-orang yang tidak berkemampuan menjadi ikut menaggung dosa dikarenakan untidak mensuport masyarakat untuk ikut mendukungnya. (Zaidi Ismail, 2007).

Al-Ghazali sebagaimana dikutip oleh Zaidi Isma'il (2007), menyatakan bahwa: "dosa tidak menuntut ilmu fardhu kifayah adalah masuk dalam kategori perbuatan membinasakan diri-sendiri, yang hal tersebut sangat dilarang oleh Allah SWT. Hal ini sebagaimana ditegaskan oleh Allah dalam al-Qur'an surah Al-Baqarah ayat I95 sebagai berikut: "dan janganlah kamu menjatuhkan dirimu sendiri ke dalam kebinasaan, dan berbuat baiklah, karena sesungguhnya Allah menyukai orang-orang yang berbuat baik".

Sebagai contoh misalnya, jika tidak ada umat Islam yang berupaya mendalami dan mengembangkan ilmu-ilmu berdasarkan nilai-nilai Islam (Islamisasi), maka sangat mungkin umat Islam ke depan akan mengalami kerusakan akibat terinfiltrasi pandangan hidup yang liberal dan sekular. Rusaknya pandangan hidup umat Islam bisa berimplikasi pada rusaknya ilmu pengetahuan, dan rusaknya ilmu pengetahuan akan mengakibatkan rusaknya amal perbuatan seorang muslim. Pada akhirnya akan peradaban Islam tidak akan bisa tumbuh dan berkembang sebagaimana mestinya.

Pada era postmodernitas seperti yang terjadi dewasa ini dimana perkembangan ilmu pengetahuan dan teknologi informasi begitu pesat, bahkan belakangan telah melahirkan sebuah generasi baru, yakni generasi millenial penguasaan ilmu dan teknologi informasi bagi umat Islam menjadi sangat penting. Penguasaan ilmu ini bisa meningkatkan kewibawaan umat Islam di mata umat lain. Untuk itu maka umat Islam harus memperkuat dari sisi ini.

Wan Daun Wan Noor dalam The Educational Philosophy and Practice of Syeed Mumahhad Naquib a-Attas: An Exposition of the Orignal Concept of Islamization; menyatakan bahwa dalam konteks kehidupan pribadi, penguasaan ilmu pengetahuan dan teknologi dalam kerangka berfikir Islamic worldview memiliki efek yang dapat membahagiakan ruhani bagi pelakunya, bukan sebaliknya menimbulkan kesengsaraan, anarkisme ruhani sekaligus akal. Sedangkan dalam konteks kehidupan masyarakat sudah barang tentu akan melahirkan keteraturan, keharmonisan, dan keadilan, bukan sebaliknya menimbulkan kekacauan dan anarkisme sosial.

Konferensi Dunia Pertama Tentang Pendidikan Islam pada tahun 1977 yang dihadiri oleh 307 pakar pendidikan dari seluruh penjuru dunia, telah merekomendaskan agar umat Islam membangkitkan kembali spirit keilmuan yang dahulu pernah digelorakan oleh para ilmuwan muslim pada era keemasan. Mereka telah berhasil mengantarkan umat Islam mencapai 
puncak peradaban ilmu. Apa yang menjadi sebab-sebab kemajuan dan apa pula yang menyebabkan kemunduran peradaban ilmu pada saat itu harus dikaji dengan seksama supaya dapat diambil sebagai pelajaran guna membangkitkan kembali peradaban Islam.

\section{C.IMPLIKASIDALAMPRAKTIKKEPENDIDIKAN}

Konsep ilmu dalam Islam sebagaimana diuraikan di atas membawa implikasi ataupun konsekuensi logis dalam beberapa aspek penting praktik kependidikan. Beberapa implikasi tersebut diantaranya akan diuraikan dalam pembahasan berikut ini.

\section{Implikasi dalam Tujuan Pendidikan}

Saat ini bangsa Indonesia tengah dilanda krisis dalam berbagai bidang, yang yang sangat sulit diatasi. Hal ini karena krisis yang terjadi telah memasuki wilayah yang sangat fundamental bagi berdiri kokohnya sebuah bangsa, yakni krisis karakter atau akhlak bangsa.

Munculnya berbagai kejadian yang mengarah pada pelanggaran etika seperti adanya perubahan gaya hidup masyarakat yang cenderung tidak menghiraukan lagi adab, semakin memperkuat asusmsi bahwa bangsa Indonesia saat telah banyak melalaikan adab. Saat ini orang yang tidak berakhlak dan hina dan bodoh dapat dinilai sebagai orang yang terhormat karena kekayaannnya, ataupun ketampanan dan kecantikannnya. Sepandai apapun seseorang kalau tidak memiliki harta yang banyak tidak akan mendapatkan penghormatan sebagaimana mestinya.

Juara kontes Miss Universe akan jauh lebih dihormati daripada seorang pelajar yang berhasil meraih medali emas diajang olympiade Fisika. Penyambutan pejabat nagara atas prestasi juara olahraga akan jauh lebih meriah dibandingkan penyambutan terhadap orang yang meraih prestasi tingkat dunia di bidang Musabaqah Tilawatil Qur'an, dan sebagainya.

Orang mudah sekali melakukan korupsi dengan jumlah yang spektakuler. Bahkan korupsi ini telah dilakukan secara sistematis oleh para oknum yang seharusnya memberantas korupsi. Jika dahulu korupsi hanya dilakukan oleh para pejabat ditingkatan hulu, sekarang sudah merata dari hulu sampai ke hilir. Lantas dimana letak kesalahannya?

Kesalahannya adalah terletak pada dunia pendidian kita. Dunia pendidikan kita saat ini talah jauh meninggalkan adab, termasuk di dalamnya yang terkait dengan adab ilmu itu sendiri. Ismail Raji al-Faruqi bahkan menyatakan bahwa masalah terbesar dunia Islam saat ini adalah berkaitan dengan krisis epistemologi. Ilmuan muslim lebih tertarik mengikuti cara berfikir ilmuwan-ilmuwan Barat daripada mengembangkan pemikiran Islam. Ilmu dikembangkan bebas dari nilainilai ketuhanan. Akibat krisis epistemologi ini muncullah krisis-krisis dalam berbagai aspek kehidupan lainnya.

Di dalam konsep adab terdapat dua unsur, yakni ilmu dan amal. Ilmu membuat seseorang mengenal dengan benar susunan martabat berperingkat segala sesuatu yang ada di alam semesta ini. Semetara amal yang mendorong seseorang untuk melakukan perbuatanperbuatan yang bermoral. Sudah banyak sekali ulama yang menaruh perhatian besar pada masalah adab ini. KH Hasyim Asy'ari, misalnya, dalam kitabnya, $\square$ dabul $\square \lim$ wal-Muta'allim, mengutip pendapat Imam Syafí i yang menjelaskan begitu pentingnya kedudukan adab dalam Islam. Bahkan, beliau menyatakan "mengejar adab laksana seorang ibu yang mengejar anak satusatunya yang hilang","

Selanjutnya, KH. Hasyim Asy'ari dengan menyitir pendapat beberapa ulama sebelumnya, menyatakan bahwa : " at-Tawhiidu yujiibul iimaana, faman la iimaana lah laa tawhiida lahu wal iimaanu yuujiibu al-Syariata, faman laa syari’ata lahu, laa iimaana lahu wala tawhiida lahu, wa al-Syarii’ atu yuujiibu al-adaba, faman laa aadaba lahu laa syari’ata lahu wala iimaana lahu, wala tawhiida lahu” (Adian, 20I22)

Maksudnya adalah bahwa tauhid mewajibkan wujudnya iman, barang siapa yang tidak beriman maka dia tidak bertauhid. Iman mewajibkan wujudnya syar'’at, barang siapa yang tidak bersyari'at, maka ia tidak beriman dan tidak bertauhid. Syari'at mewajibkan wujudnya adab. Barang siapa yang tidak beradab maka dia tidak bersyari’at, tidak beriman, dan juga tidak bertauhid.

Dengan demikian adab memiliki posisi yang sangat sentral dalam ajaran Islam. Begitu sentralnya posisi adab ini maka tidak adanya adab dapat membatalkan ketauhidan kita.

Sebenarnya istilah yang komprehensif untuk 
pendidikan Islam sendiri adalah ta'dib. Di dalam istilah ini mencakup makna yag terdapat pada istilah tarbiyah dan tálim. Selama ini implementasi konsep pedidikan Islam lebih mengacu pada makna tarbiyah atau ta'lim.

Dengan mengacu pada istilah ta'dib maka pendidikan Islam akan menjadi ideal sebab di dalam istilah adab sendiri sudah menakup makna ilmu, karenanya ilmu tidak dapat ditransformasikan dan difahamkan kepada peserta didik kecuali jika peserta didik tersebut memiliki adab yang tepat terhadap berbagai bidang ilmu pengetahuan.

Ilmu yang telah dipelajari dan ditekuni sedemikian rupa, dan yang dimotivasi dengan iman lalu diamalkan dalam kehidupan, maka konsep ta'dib dengan sendirinya telahh diimplementasikan. Ilmu yang dicapai melalui proses ta'dib inilah yang akan melahirkan sebuah peradaban yang bermartabat, yakni peradaban Islam. F. Rosenthal meyatakan; "ilm is one those that have dominated Islam and given Muslim civilization is distinctive shape and complexion. In fact there is one other concept that has been operative as of Muslim civilization in all its aspect to the same extent as 'ilm” (Rosental, t.th.). Artinya kurang lebih: " Ilmu adalah salah satu konsep yang mendominasi Islam dan yang memberi bentuk dan karakter yang khas terhadap peradaban Muslim. Sebenarnya tidak ada konsep lain yang sebanding dengan konsep ilmu yang secara efektif menjadi faktor penentu dalam peradaban Muslim dalam berbagai aspek.

Praktik kependidikan Islam selama ini lebih ditekankan sebatas makna tarbiyah dan ta'lim. Hal ini tidak terlepas dari infiltrasi worldview Barat yang didasarkan pada prinsi-prinsip dualisme, sekularisme, liberalisme, dan dan niai-nilai peradaban Barat lainnya. Dengan rancu atau kaburnya nilai-nilai adab dalam dunia pendidikan Islam maka proses pendidikan dan pembelajaran yang ada terlepas dari nilai-nilai ketuhanan. Padahal dalam konsep Islam ilmu bersumber dari Allah dan proses pencapaian ilmu pun tidak bisa lepas dari peran aktif Allah. Allah-lah pemberi anugerah ilmu yang sejati. Tanpa anugerah Allah seseorang tidak akan mampu mendapatkan ilmu pengetahuan.

Kerancuan dan kekaburan nilai-nilai adab itu menyebabkan lahirnya kezaliman (zulm), kebodohan (jahl), dan kegilaan (junun). Zalim maknanya adalah tidak dapat menempatkan sesuatu sesuai dengan tempatnya. Bodoh maknanya adalah menggunakan cara-cara yang tidak benar untuk mencapai tujuan. Sedangkan Gila berarti menggunaan cara-cara yang salah untuk mencapai tujuan yang salah. Dengan kata lain ia menghalalkan segala cara untuk mencapai tujuan yang dicita-citakan.

Dengan demikian agar seseorang tidak zalim, tidak bodoh, dan tidak gila, maka ia harus belajar adab secara tuntas. Jadi probem utama pendidikan Islam bukan masalah banyaknya umat yang masih buta huruf, tetapi lebih karena umat Islam banyak yang salah jalan dan salah di dalam mencapai tujuan hidupnya. Dampaknya pendidikan yang menjadi sarana pengembangan ilmu pengetahuan ini telah diracuni dengan padangan hidup asing yag bertentangan dengan pandangan hidup Islam, terutama western worldview. Dampak yang lebih dahsyat adalah bergesernya makna ilmu yang sebenarnya. Apa yang disebut ilmu itu adalah yang masuk kategori sains dalam peradaban Barat (Hamid Fahmy, 2005).

Dengan berpedoman pada aliran episteologi Kritisisme Kant, banyak pemikir muslim yang meyakini bahwa apa yang disebut ilmu pengetahuan adalah yang objek studinya bisa di tangkap oleh panca indera, bisa diverifikasi, dan juga bisa dicerna oleh akal (rasio). Dengan menggunakan paradigma positivisme mereka berkeyakinan bahwa syarat objek ilmu adalah: observable (bisa diamati), testable (bisa diuji), predictable (bisa dprediksi), reapetable (diulang-ulang hasilnya sama). Dengan paradigma kritisisme dan positivisme tersebut maka hal-hal yang bersifat metafisis seperti adanya Allah, surga, neraka, pahala, dosa, kehidupan akhirat, dan lain-lain dianggap menjadi sesuatu yang tidak memiliki nilai kebenaran epistemologis.

Pendidikan yang tidak mengindahkan adab tidak akan mampu menghindarkan seorang muslim dari sifat zalim, bodoh, dan gila. Munculnya kekacauan berfikir , penyelewengan dalam pemanfaatan ilmu pengetahuan, pelacuran intellektual dan sebagainya merupakan bukti kegagalan dunia pendidikan dalam menanamkan adab kepada para peserta didik. Kehancuran adab ini akan menjadi kendala yang serius bagi masyarakat guna 
munculnya kader-kader pemimpin masa depan yang berkualitas di berbagai bidang. Bahkan sebaliknya hal ini bisa memicu munculnya pemimpin-pemimpin "palsu" yang lebih merusak masyarakat daripada memperbaikinya. Hal ini disebabkan kualitas lembaga pendidikan yang telah melupakan masalah adab.

Untuk memperbaikinya, umat Islam harus mengorientasikan kembali tujuan pendidikan, yakni untuk membangun individu-individu yang memahami posisinya di hadapan Allah, di hadapan umat, dan di hadapan dirinya sendiri. Dengan ungkapan lain, pembangunan manusia harus diarahkan pada konsep pengembangan individu yang beradab.

Bagi al-Attas pembangunan individu semacam ini dapat dilaksanakan melalui pendidikan di univeritas. Universitas memiliki peran yang sangat strategis dalam hal ini. Namun demikian worldview pada civitas akademiknya, baik menyangkut tenaga pendidik dan tenaga kependidikannya harus diperbaiki terlebih dahulu, supaya pemahaman terhadap nilai-nilai ajaran Islam dapat berjalan dengan baik, yang ada akhirnya mampu mencetak ulama dan pemimpin muslim yang memiliki Islamic wordlview kuat (Hamid Fahmy, 2005).

Dipilihnya pendidikan tingkat universitas untuk pembentukan adab merupakan tradisi yang sudah lama berkembang di dunia Islam. Penekanan pada pendidikan dasar dan menengah untuk pembentukan dan pengembangan adab disinyalir karena pendidikan kita telah terinfilterasi pendidikan Barat. Di samping itu universitas juga merupakan kawah canradimuka untuk pengkaderan para pemimpin ummat. Hampir di setiap negara pendidikan tinggi dijadikan sebagai tempat pengkaderan baik dalam bentuk pendidikan maupun pelatihan untuk melahirkan pemimpin yang unggul.

Pendidikan dasar dan menengah sebaik apapun prosesnya tetap saja tidak akan mampu melahirkan pemimpin yang unggul. Ia hanya merupakan terminal antara untuk mengantarkan peserta didik memasuki jenjang pendidikan di universitas. Bagaimanapun hebatnya pembangunan pednidikan dasar dan menengah, jika pendidikan tingginya tidak mengembangan ilmunya berdasarkan epistemologi dan worldview Islam, dapat dipastikan akan gagal. Dengan memfokuskan pembangunan pendidikan tingkat universitas, maka kelemahan-kelemahan yang ada pada pendidikan dasar dan menengah akan bisa diatasi.

Supaya perguruan tinggi (universitas) menjadi sarana pengembangan sumber daya insani, maka setiap aktivitas yang ada di perguruan tinggi harus mencerinkan sebuah upaya pembentukan insan kamil. Umat Islam memiliki figur yang menjadi contoh konkret dari insan kamil, yakni Nabi Muhammad Saw. Oleh karena itu Perguruan Tinggi Islam harus merefleksikan Nabi Muhammad Saw. sebagai figur sentral dalam pengembangan ilmu dan amal, agar terlahir indivduindivdu yang beradab. (al-Attas, I98I).

Tidak sama dengan universitas Islam, universitas di negara-negara Barat pada umumnya merefleksikan kesobongan manusia. Walaupun mereka juga memiliki konsep manusia sempurna, akan tetapi karena dominasi faham humanisme sekular, manusia ditempatkan pada posisi setinggi-tingginya, bahkan lebih tinggi dari Tuhan. Bagi mereka "manusia adalah ukuran dari segala sesuatu, segala sesuatu yang ada adalah ada, dan segala sesuatu yang tidak ada adalah tidak ada" (Hamid Fahmy, 2005). 2. Implikasi dalam Bidang Kurikulum

Dalam era dimana umat Islam dituntut untuk menimba ilmu agama dan ilmu umum, klasifikasi ilmu menurut al-Ghazali yakni ada ilmu fardhu 'ain dan ilmu fardhu kifayah masih relevan untuk diimplementasikan. Ilmu fardhu 'ain berkaitan dengan masalah-masalah ketuhanan. Ilmu fardhu kifayah menitik beratkan pada pola relasi antar manusia, dan nilai-nilai moral lainnya yang membentuk pandangan tentang manusia dan alam semesta. Klasifikasi ilmu fardhu 'ain dan fardhu kifayah tidak boleh dilihat secara dikotomis, sebab ia hanya merupakan tingkatan (hirarki) ilmu berdasarkan tingkat kebenarannya. Dalam hal ini harus dilihat sebagai satukesatuan, dimana ilmu fardhu 'ain merupakan asas dan rujukan bagi ilmu fardhu kifayah.

Kurikulum pendidikan Islam seharusnya pembelajaran ilmu-ilmu fardhu 'ain terutama ilmu tentang aqidah dan ilmu-ilmu tentang ibadah dan akhlak tidak cukup hanya diberikan pada pendidikan dasar dan menengah, akan tetapi juga harus diberikan di perguruan tinggi, yang ditekankan pada pemahaman knsep-konsep kunci dalam Islam. Materi dasar tentang aqidah yang diberikan ada tingkat pendidikan dasar dan menengah 
seharusnya dikembangkan dalam bentuk materi yang lebih tinggi yakni Mata Kuliah Ilmu Kalam dan filsafat Islam, yang di dalamnya dikaji secara mendalam konsepkonsep tentang Tuhan, manusia, alam, ilmu, kehidupan, kebahagiaan, kebenaran, kebajikan, keadilan, dan lainlain.

Jika konsep-konsep tersebut diajarkan dan dipahami oleh peserta didik, maka akan dapat menjadi pondasi dalam mengkaji ilmu-ilmu fardhu kifayah. Sumber pengetahuan indrawi, akli, dan intuisi yang di dalam konsep epistemologi Barat dioperasinalkan sendiri-sendiri di sini bisa diintegrasikan. Maknanya pola pikir dualistik sebagaimana yang dilakukan oleh ilmuwan-ilmuwan Barat seperti; objektif dan subjektf, idealis-realis, harus ditinggalkan. Dengan jalan ini dikotomi ilmu pengetahuan yang merupakan ciri khas peradaban Barat, sebagaimana juga telah banyak dipraktekkan oleh lembaga-lembaga pendidikan Islam dewasa ini lambat laun bisa ditiadakan.

Bagi al-Attas setiap orang Islam wajib wajib mendalami ilmu-ilmu fardhu kifayah sesuai dengan minat dan kapasitas intellektual masing-masing. Ilmu fardhu 'ain bagi mahasiswa fakultas Syariah, misalnya berbeda dengan ilmu fardhu 'ain siswa Madrasah Aliyah atau mahasiswa Fakultas Psikologi. Apabila seluruh ilmuwan mendalami ilmu-ilmu fardhu 'ain sesuai bidang masingmasing, pada tingkat epistemologis ilmu fardhu 'ain ini akan mengintegrasikan berbagai disiplin ilmu yang masuk dalam kategori ilmu-ilmu fardhu kifayah, seperti; sosial humaniora, ilmu alam, antropologi, sosiologi, dan lain sebagainya.

Pemikiran al-Ghazali tentang ilmu fardhu 'ain dan fardhu kifayah sebagaiman diuraikan di atas, selama ini belum banyak diketahui di kalangan lembaga pendidikan Islam. Seandainya diketahui pun pemahaman akan hal ini masih cenderung kurang tepat, kalau tidak bisa dikatakan salah. Sebagian besar aktoraktor pendidikan belum mengkonseptualisasikan dan mempraktekkan hal tersebut secara akademik. Klasifikasi ini harus dikedepankkan pada jenjang pendidikan tingkat universitas, karena hal ini berhubungan dengan konsep epistemologi yang cukup rumit, yang tidak mungkin untuk dibebankan kepada lembaga pendidikan dasar dan menengah.

\section{Implikasi Terhadap Proses Pembelajaran}

Konsep ilmu dalam Islam di samping berimplikasi pada orientasi tujuan pendidikan dan bangunan kurikulum pendidikan Islam, juga berimplikasi pada proses pembelajaran di kelas. Dalam Islam, kehidupan manusia sejak bangun tidur hingga tidur lagi terikat dengan adab-adab. Adab pada hakikatnya adalah perbuatan yang betul yang muncul dari disiplin diri yang bersumber dari ilmu dan hikmah. Adab adalah perbuatan yang betul dalam hal apa saja. Seseorang yang mau tidur ada adabnya, yakni bersuci terlebih dahulu, berdoa sebelum tidur, posisi kepala di utara, tubuh miring ke kanan menghadap kiblat. Setelah bangun tidur dia juga harus berdoa. Mau masuk kamar mandi ada adabnya, yakni berdoa terlebih dahulu, melangkah masuk dengan kaki kiri dan keluar dengan kaki kanan terlebih dahulu, dan sebagainya. Jadi tidak ada perbuatan seorang muslim yang tidak terikat adab.

Demikian pula dalam hal proses pembelajaran di kelas, baik guru maupun murid terikat adab-adab, baik adab terhadap Allah, adab terhadap ilmu itu sendiri, maupun adab dalam hal hubungan antara guru dengan murid atau peserta didik. Adab terhadap Allah misalnya, baik guru maupun peserta didik harus selalu memulai dan mengakhiri proses pembelajaran dengan berdo'a untuk dibukakan pintu hati guna masuknya ilmu, dan senantiasa mohon untuk diberi kefahaman.

Guru harus senantiasa mengingatkan peserta didik untuk meluruskan niat di dalam menimba ilmu, yakni sematamata untuk mencari ridha Allah dan berharap pahala pada-Nya. Mengingatkan agar senantiasa menghargai ilmu, menghormati guru, menghormati teman, bersikap ta'dhim, menghindari akhlak tercela, bersyukur, lillahi ta'ala, wara' ketika belajar, rendah hati, dan senantiasa positive thinking. (As'ad, 2007)

Tidak kalah pentingnya guru juga harus senantiasa mengingatkan peserta didik untuk memuliakan majelis ilmu. Dalam proses pembelajaran di kelas peserta didik harus memperhatikan penjelasan guru dengan sungguh-sungguh. Tidak diperkenankan berbuat gaduh, yang bisa mengganggu proses belajarmengajar.

Terkait dengan adab menimba ilmu dan adab yang terkait hubungan antara guru dengan murid, 
beberapa ulama telah menulisnya. Az-Zarnuji misalnya menulis kitab Ta'limul Muta'alim, KH. Wahid Hasyim menulis Adabul Alim wal Muta'alim, dan sebagainya.

Dalam Ta’limul Muta'alim (As’ad, 2007) misalnya, az-Zarnuji menyebutkan beberapa adab yang harus dipatuhi oleh peserta didik dalam menimba ilmu; antara lain I) Peserta didik harus mendahulukan kesucian jiwa, 2) Menyedikitkan hubungan dengan urusan-urusan duniawi, 3) Bersikap rendah diri, tidak sombong, dan senantiasa menghormati guru, 4) Jika masih baru tidak boleh terlibat dalam perdebatan, 5) Memilih satu disiplin ilmu, 6) Tidak diperkenanan mempelajari semua bidang ilmu sekaligus, 7) Mengetahui sebab-sebab kemuliaan ilmu, 8) Tujuan menimba ilmu adalah untuk kesucian jiwa dan mencari fadhilah dari Allah, bukan untuk mmencari materi, 8) Memahami keterkaitan ilmu dengan tujuan hidup, II) menyerahkan urusan kepada gurunya.

Dalam hal adab hubungan antara guru dengan peserta didik ada adab-adab yang harus dipatuhi, antara lain: I) Menghindari banyak bicara dengan guru, 2) Tidak memulai bicara dengan guru jika tidak diajak bicara, 3) Tidak bertanya sebelum minta ijin, 4) Tidak diperkenanan berbicara dengan tertawa dengan guru, 5) bersikap tawadhu' di hadapan guru, 6) Tidak duduk di tempat duduk guru, dan 7) Tidak melakukan hal-hal yang menyinggung perasaan guru.

Adab-adab tersebut harus diimplementasikan dalam proses pembelajaran, agar dapat melahirkan perserta didik yang memiliki adab. Dengan adab inilah peserta didik akan dimudahkan oleh Allah Swt untuk mendapatkan kefahaman (ilmu), karena karakter ilmu tidak akan masuk kecuali dengan cara-cara yang beradab. Ilmu yang diperoleh melalui cara demikian sajalah yang pada akhhirnya akan membawa manfaat untuk kemajuan umat dan peradaban Islam.

\section{KESIMPULAN}

Berdasarkan pembahasan yang telah diuraikan di atas, maka dapat ditarik sejumlah kesimpulan sebagai berikut:

I. Konsep ilmu dalam Islam berbeda dengan konsep ilmu dalam peradaban Barat. Dalam perdaban barat yang dimaksud denngan ilmu adalah sains. Sementara dalam konsep Islam sains hanya merupakan salah satu bagian dari ilmu pengetahun. Dalam Islam proses keilmuan senantiasa melibatkan Allah sebagai sumber ilmu, sedangkan dalam peradaban Barat proses keilmuan diyakini sebagai murni upaya manusia.

2. Ilmu dalam Islam terkait erat dengan adab, sehingga ilmu hanya dapat diperoleh dengan cara-cara yang beradab, sementara dalam peradaban Barat tidk demikian.

3. Ilmu dalam Islam meliputi ilmu fardhu 'ain dan ilmu fardhu kifayah yang dalam implementasinya bersifat dinamis. Fardhu kifayah bagi seseorang, bisa menjadi fardhu 'ain bagi orang lain, dan sebaliknya.

4. Konsep-konsep tersebut berimplikasi pada orientasi tujuan pendidikan, kurikulum, dan proses pembelajaran di kelas. Orientasi tujuan pendidikan Islam yaitu untuk mewujudkan manusia-manusia yang beradab. Kurikulum pendidikan Islam dalam berbagai tingkatan yang harus bersifat inegral, dan tidak dikotomis sebagaimana konsep Barat. Proses pembelajaran di kelas maupun di luar kelas harus mengimelmentasikan adab ilmu dan adab hubungan guru dan peserta

\section{KEPUSTAKAAN}

Setia, Dr. Adi, 2005, Epistemologi Islam Menurut alAttas Satu Uraian Ringkas, dalam Islamia, Th.I No 6, Juli-September

Armas, Adnin, MA, 2005, Westernisasi dan Islamisasi Ilmu, dalam Islamia, Th.I No 6, Juli-September

Anshari, Endang Saifuddin, I985, Ilmu, Filsafat dan Agama, Bandung: Pustaka

Al-Attas, Syed Muhammad Naquib, 2002, Prolegomena to The Mathapycic of Islam, Kuala Lumpur: International Institute of Islamic Thought and Civilization, (ISTAC)

Al-Attas, Syed Muhammad Naquib, I98I, Islam dan Secularisme, Terj. Karsidjo Djojosuwarno, Bandung : Pustaka

As'ad, Aly, 2007, Terjemah Ta’limul Muta'allim Bimbingan Bagi Penuntut Ilmu, Kudus: Menara Zarkasy, Hamid Fahmy, Dr., 2006, Islam Sebagai Pandangan Hidup, Makalah Two Day Workshop 
on Islamic Civilization Studies, Bandungan, 2I-

23 Juni

Zarkasy, Hamid Fahmy, 2005, Pandangan Hidup slam,

Pengetahan dan Pendidikan Islam, Makalah disampaikan pada Workshop Ilmu Pengethaan dan Pendidikan di Sekolah Tinggi Lukmanul Hakim, Hidayatullah, Surabaya, I2-I3 Agustus

Isma'il, Dr. Mohd. Zaidi Isma’il, 2007, Faham (Konsep) Ilmu dalam Islam: Mengenali Dimensi-dimensi Ilmu melalui Takrifannya, Makalah Studi Peradaban Islam, Unissula, I0-II Nopember

Rosental, Frans, tth, Knowledge Triumphant, The Concept of Knowledge in Medieval Islam, E.J. Brill: Leiden

Daud, Wan Mohd Wan, 1998, Filsafat dan Praktik Pendidikan Islam Syed M. Naquib Al-Attas, Bandung: Mizan 